\title{
The Influence of Chief Executive Officers' Traits on Financial Risk Management Perceptions: Evidence from Malaysia
}

\author{
Ahmad Shukri Yazid (Corresponding author) \\ Department of Banking \& Finance \\ Universiti Sultan Zainal Abidin, Malaysia \\ Mohd Rasid Hussin \\ College of Business \\ Universiti Utara Malaysia, Malaysia \\ Wan Norhayate Wan Daud \\ Dept. of Banking \& Finance \\ Universiti Sultan Zainal Abidin, Malaysia
}

Received: January 28, 2012

Accepted: February 28, $2012 \quad$ Published: April 1, 2012

doi:10.5539/ijef.v4n4p78

URL: http://dx.doi.org/10.5539/ijef.v4n4p78

\begin{abstract}
The main aimed of this study is to examine the Chief Executive Officers' (CEOs') traits in relation to the perceptions of financial risk management during three time periods, namely, before the financial crisis 1997, during the crisis and after the crisis. A survey questionnaire was designed and distributed to CEOs of public listed companies under the Malaysian Bourse. A total of 54 CEOs responded to the survey. The main findings of the study are as follows: a) Before and after the crisis, CEOs gave the highest priority to business risk as compared to financial risk; b) During the crisis, CEOs gave a higher priority to financial risk; c) Younger CEOs attributed the highest priority to financial risk; d) More experienced CEOs attributed the highest priority to foreign exchange and interest rate risk and e) Malay CEOs gave a higher priority to financial risk than Chinese CEOs.
\end{abstract}

Keywords: Financial Risk Management, Chief executive officers traits, Public listed companies, Malaysia

\section{Introduction}

Financial risk management has become a critical issue among Malaysian major companies since the Asian Financial crisis in 1997. Before the crisis most of the Malaysian companies were very complacent in managing financial risk (Yazid et al., 2011). As a result, many companies suffered huge financial losses. For example, the Malaysian Airline System experienced foreign exchange losses amounting to M\$718.4 (Business Times, May 30, 1998).

It was argued by many authors (e.g., Yazid et. Al, 2011; Stoh, 2005) that company could benefit from a proper implementation of risk management program. Risk management is a proactive way of managing risks exposed by companies. In particular, financial risk management is a structured approach of managing financial risks, namely, foreign exchange risk, interest rate risk and commodity price risk.

When come to managing risks, MacCrimmon et. al (1990) suggested that CEOs' traits may influence their perception to risk and thus, may lead to differences in financial risk management practices. Thus, the main objective of this study is to investigate the relationship between CEOs' traits and their perceptions and financial risk management practices in the context of Malaysian major corporations during three time periods, namely, before the 1997 financial crisis, during the crisis and after the crisis. This paper is structured as follows: next section discusses several definitions of financial risk management, CEOs' traits and their perceptions of financial risk management. This is followed by examining the perceptions of financial risk by the CEOs as well as relationship between CEOs' traits and financial risk management perceptions. Finally, this chapter ends with a brief summary of important findings and some concluding remarks.

\section{Significant of the Study}

Financial risk management has become one of the critical factors in determining corporate survival. Lessons learnt during the Financial Crisis in 1997 have taught many companies not to be complacent in managing risk. 
Furthermore, studies on financial risk management have been very scarce for developing countries such as Malaysia. Thus, this study adds to the existing literature and provides a better understanding on how CEOs' trait might influence their perceptions of financial risk management.

\section{Literature Review}

\subsection{Definitions of Financial Risk Management}

One of the earliest definitions of financial risk management was given by Shapiro et al. (1985). They referred to financial risk management as a risk-reduction technique involving the lowering the debt-equity ratio, the buying and selling forwards or futures contracts, and the purchase of insurance. Campbell and Kracaw (1993) defined financial risk management as the design and implementation of systems or procedures for controlling financial risks. Accordingly, financial risk management is a systematic approach that can be used by a firm to manage commodity prices, foreign exchange rates and interest rate risks. In this context, it has been argued that the use of financial risk management will ensure not only a firm's survival but also increase its value (Rawls, et. al, 1990; Nance, et. al, 1993).

Santomero (1995) referred to financial risk management as a process whereby a firm engages in financial transactions that reduce the volatility of its earnings. Financial risk management using financial market instruments like futures, options, and forwards can achieve these goals. Eales (1995) interpreted financial risk management as the controlling of the possibility or chance of suffering a monetary loss. In the context of corporate finance, the activities involved in controlling such risk are often referred to as hedging.

The definitions given by the previous authors have several commonalties. Most of them view financial risk management as the steps taken by a firm to avoid or minimise financial risks. These steps, in turn, are assumed to involve the use of financial instruments such as forwards, futures, options and swaps.

For the purpose of this study, financial risk management is defined as the steps taken by a firm to avoid, minimise or control financial risks by using financial instruments like futures, forwards, options and swaps.

\subsection{CEOs' Risk Perceptions}

The role of CEOs was expected to be crucial in influencing the management of risks. A study by Penafort et. al (1996) suggested that top management including CEOs play a crucial role in ensuring firms' strategies are successfully implemented. It was further argued by Ankrom (1974) that foreign exchange risk management must involve top level management. Accordingly, the decision to engage in financial risk management must be made clear by CEOs so that CEOs feel comfortable undertaking financial risk management for their firms. MacCrimmon and Wehrung (1990) conducted a study on more than 500 top-level executives in an effort to examine their risk taking behaviours. They examined their behaviour in accordance to: a) hypothetical situations underlying the theory of risk; b) revealed choices in naturally occurring events; and c) attitudes towards risk taking. They found that the most successful executives were the biggest risk takers and older executives were the most risk averse. In addition, Brehmer (1987) argued that people's attitude towards risk taking may depend on their judgement based on personal experience. If they remember a certain event that led to losses in the past, they may give higher consideration for that risk and vice-versa. Thus, CEOs' experience may affect their decisions on the management of financial risks.

In another study on risk, Hovden and Larsson (1987) suggested that CEOs' risk taking behaviour to some extend depend on culture. In addition, Theil and Ferguson (2004) argued that culture influences the way people perceive and manage risks. In the Malaysian context, Manab (2008) showed that culture plays a significant role in Enterprise Wide Risk Management practices. Therefore, it is expected that there are some differences and similarities between groups in a society. In the case of Malaysian companies, their top management usually comprises of either Malays or Chinese. Hence, it is appropriate to examine the ethnic groups of CEOs in relation to their perceptions and practices of financial risks.

Therefore, the above discussions provide incentive for the researcher to examine the CEOs' traits in relation to financial risk management perceptions.

\section{Methodology}

\subsection{Population and Sample}

The population under study consists of public listed companies under the Malaysian bourse excluding financial companies. The financial companies were not included for obvious reason that they have different risk exposures. For the purpose of this study a sample of ninety (90) companies was selected at random.

\subsection{Data Collection}

The unit of analysis for this study was CEOs of the Malaysian companies listed in the Malaysian Bourse. A survey questionnaire was sent to a sample of 90 companies and 54 companies responded which represent about 61 percent 
response rate. The survey response rate was considered high compared to a typical mail survey of 20 to 30 percent (Vaus, 1993).

\subsection{Data Analysis}

Data was analysed using SPSS. Descriptive analysis was first undertaken in particular bar graph on CEOs' risk perceptions. Kruskal-Wallis test was used to examine the CEOs' traits and risk management perceptions.

\section{Findings and Discussions}

\subsection{CEOs' Perceptions of Major and Financial Risks}

Question 2 in Section B of the survey questionnaire asked CEOs about their perceptions of major risks. The major risks considered in this study were business risks, financial risks, and political risks. Question 3 in Section B of the survey questionnaire asked about CEOs' perceptions of financial risks, namely, interest rate, foreign exchange and commodity price risks.

As shown in Figure 1, among CEOs who managed financial risks, $35.3 \%$ gave the highest priority to business risks in the period before crisis as compared to $11.8 \%$ and $2 \%$ for financial risks and political risks, respectively. During the crisis, their perceptions of risks changed. The percentage that attributed the highest priority to financial risks and political risks increased to $52.9 \%$ and $11.8 \%$, respectively. However, the percentage for business risks decreased to $33.3 \%$. Finally, in the period after the crisis, the percentages for business risks, financial risks and political risks were $44.2 \%, 40.4 \%$ and $17.3 \%$, respectively.

For CEOs who did not manage financial risks, $17.6 \%$ perceived business risks to be the highest priority in the period before the crisis as compared to only 5.8\% for financial risks (Figure 2). During the crisis, $23.5 \%$ attributed the highest priority to financial risks as compared to only $15.6 \%$ for business risks. However, in the current period, $23 \%$ attributed the highest priority to business risks while the percentage for financial risks decreased to $7.7 \%$.

Both groups seemed to give more priority to business risks in the period before crisis and in the period after the crisis, while financial risks were given the highest priority during the crisis. This could be due to a broader definition of business risks which includes uncertainties in firms' overall activities that were outside their control.

The results also show that only $19.6 \%$ of CEOs in companies with financial risk management practices perceived the highest priority to foreign exchange risk in the period before crisis. However, the percentages increased to 56.9\% during the crisis and $30.8 \%$ in the period after the crisis (Figure 3). These CEOs appear to have given little attention to foreign exchange risk in the period before the crisis. Only after the crisis did they begin to give attention to the risk. On the other hand, the percentages for CEOs in companies without financial risk management who perceived foreign exchange risk as important were $9.9 \%, 9.8 \%$ and $11.5 \%$ for the three periods, respectively (Figure 4). Accordingly, it is not surprising that they were not involved in financial risk management.

Financial risks were given lesser priority in the period before crisis. Consequently, they also gave less priority to interest rates, foreign exchange and commodity price risks. This result is possibly due to the stable Malaysian ringgit and a booming economy. However, it is not surprising that these companies gave a higher priority to financial risks during the crisis due to high volatility in interest rates and foreign exchange rates at this time. Therefore, many of these companies attributed a higher priority to foreign exchange risk because they were involved in international business, thus exposing themselves to foreign exchange risk. In the meantime, since many of them were highly leveraged, they attributed higher importance to interest rate risk. On the whole, among the three financial risks, foreign exchange risk was given the most priority, especially during the crisis.

In the period after the crisis, after the government had imposed the capital and currency control, the percentage who gave higher priority to financial risks declined again. Consequently, the percentage who attributed the highest priority to interest rates, foreign exchange and commodity price risk also decreased as compared to the crisis period. Thus, the results imply that these companies did not learn from their experience during the crisis period. They tended to ignore these risks again. Even though foreign exchange risk was not that significant due to the pegging of the Malaysian ringgit against the US dollar, they were still exposed to currency fluctuations when the US dollar weakened or strengthened against other currencies. In the short term, they might be successful with less dependence on foreign risk management, but in the long term, it could be damaging.

Overall, political risks were given the least priority for the three periods under consideration. One possible reason for these findings could be that the huge fluctuations of foreign exchange and interest rates during the crisis resulted in more attention being paid to these risks than to political risk. Many companies who had been complacent in managing financial risks before were shocked with the huge devaluation of Malaysian ringgit. 
Other reason for this phenomenon could be due to political stability in the country as well as in the ASEAN countries where most of the investments were made. However, during the crisis, the number of companies that gave the highest priority to political risk increased slightly. This possibly due to political instability at home and abroad. For example, the government of Malaysia faced a strong challenge from opposition parties especially when the Prime Minister sacked the former Deputy Prime Minister, Anuar Ibrahim (Asiaweek, January 22, 1999). The political situations in other ASEAN countries were also unstable. For example, the former President of Indonesia, Suharto, resigned due to political pressure from students (Asiaweeek, June 5, 1998).

The non-users of financial risk management gave less priority to major and financial risk as compared to the users. Business risks were given the highest priority before crisis, probably for the same reasons given for users of financial risk management. They gave the highest priority to interest rate risk due to the fact that many of them were highly leveraged. In fact, this was one of the characteristics of Malaysian companies. On the other hand, foreign exchange risk was given less priority possibly due to relatively small foreign currency exposure.

\subsection{CEOs' Traits and Financial Risk Management Perceptions}

The CEOs' characteristics examined in the present study were age, experience and ethnic group. Questions 2 and 3 in Section A of the survey questionnaire related to their age and experience of financial risk management. The age and experience of these CEOs were divided into five categories so that they were approximately normally distributed. They were arranged in ascending order, taking values from one to five. On the other hand, the ethnic groups of these CEOs comprised of either Malays or Chinese. It was believed that these factors would influence perceptions of risks and, thus, have differing impacts on the way that financial and foreign exchange risk was managed.

\subsubsection{Results: Major and Financial Risks}

As shown in Table 1, there were significant differences between CEOs' age and their perceptions of major risks in the period before crisis. In particular, $76.9 \%$ of the older CEOs gave the highest priority to business risk compared to $33.3 \%$ of the younger CEOs (Table 2). As argued above, this could be due to the broader definition used for business risk, which includes all uncertainties in relation to companies' operations. Thus, the older CEOs being more consecutive attributed greater importance to business risk. However, the younger CEOs attributed the highest priority to financial risks. This was probably due to younger CEOs being more active and willing to take more risks than the older CEOs. During the crisis and in the current period their perceptions towards major risks were the same. Perhaps all CEOs, irrespective of age, thought that higher priority must be given to major risk, especially financial risks due to foreign exchange and interest rate volatility. Furthermore, there was no significant difference between age groups for interest rate, foreign exchange and commodity price risks.

As noted earlier, experience of CEOs in financial risk management may affect their risk perceptions. The results (Table 1) showed that there was a significant difference between experience and perceptions of financial risks during the current period. More experienced CEOs (73.3\%) gave higher priority to financial risks compared to $50 \%$ of the less experienced CEOs. This implies that experience did not influence their perceptions of risks before and during crisis. During the crisis, the majority of the CEOs, irrespective of experience gave higher priority to financial risks. Considerable financial losses suffered during crisis may have led them to perceive higher importance to major risks, especially financial risks. This is consistent with Brehmer's (1987) argument that CEOs would normally remembered past bad experience. In such cases, their experiences may have leaded them to attribute higher priority to financial risks in the current period.

However, there was a significant difference between experience of CEOs and perceptions of interest rate and foreign exchange rate risks during crisis (Table 1). To be more specific, less experienced CEOs attributed higher priority to interest rate risk $(66.7 \%)$ while more experienced $(100 \%)$ ones gave a higher priority to foreign exchange risk. In addition, there was also a significant difference between CEOs' experience and perceptions of interest rate risk in the current period. About $67 \%$ of the less experienced CEOs gave a higher priority to interest rate risk as compared to $20 \%$ of the more experienced ones. This was probably due to their familiarity with interest rate futures available from the MME. Incidentally, this is the only product offered by MME and the future is only in Malaysian dollars. It appears that more experience is needed for the inclusion of other financial products, such as options and swaps.

Lastly, ethnic groups were examined in order to study their influence on risk perception. As shown in Table 1, there was a significant difference between ethnic groups and perceptions to financial risks before the crisis and in the current period. In particular, more Malay CEOs (35.7\%) attributed higher importance to financial risks than the Chinese (5.3\%) in the period before crisis. Similarly, in the current period, more Malay CEOs (78.6\%) gave a higher priority to financial risks than the Chinese (52.6\%). This result is possibly due to the risk averse culture of the 
Malays. Another possible reason could be due to the fact that Malays are still new to corporate business, especially international business.

As shown in Table 3, during the financial crisis, significant differences were evident among the CEOs' risk perceptions. For the same period, the younger CEOs' perceived the highest priority to financial risks, in particular, foreign exchange risk. This was possibly due to the volatility of foreign exchange rates during the crisis period. However, more experienced CEOs attributed the highest priority to foreign exchange risk before the crisis. One possible reason for this discrepancy could be that their increased involvement in international businesses increased their experience. And due to interest rates uncertainties, they attributed greater importance to interest rates risk in the current period. As before, more experienced CEOs gave a higher priority to interest rate risk than the less experienced ones. There was no significant difference in the perception of foreign exchange risk during crisis, probably because of the huge devaluation of the Malaysian dollar. Thus, all CEOs irrespective of experience thought that this risk must be given the most priority. Possibly due to the capital and currency control, all CEOs perceived that foreign exchange risk was not significant in the current period.

\section{Conclusion}

Some of the interesting findings from this particular study are as follows: a) Before and after the crisis, CEOs gave the highest priority to business risk as compared to financial risk; b) During the crisis, CEOs gave a higher priority to financial risk; c) Younger CEOs attributed the highest priority to financial risk; d) More experienced CEOs attributed the highest priority to foreign exchange and interest rate risk and e) Malay CEOs gave a higher priority to financial risk than Chinese CEOs.

As concerned ethnicity, the survey indicated that Malay managers relied more heavily on financial risk management than Chinese managers. These findings add to the understanding of financial risk management since earlier research did not include these variables. Malay managers, probably due to their risk averse culture and their lesser exposure to international business, tended to manage more foreign exchange risk. This, again, indicates that there may be a need for training, especially in relation to instruments used for hedging risks.

\section{References}

Ankrom, R. K. (1974). Top-Level Approach to the Foreign Exchange Problem. Harvard Business Review, 52(July August): 79 - 90.

Asiaweek. (1998). Kings Don't Fall Lightly, Suharto Legacy: Fortunes and Failings. Asiaweek. 24: 38.

Asiaweek. (1999). Flexing Political Muscle. Asiaweek, 25, 16 - 21.

Brehmer, B. (1987). The Psychology of Risk. Risk and Decisions. W. T. Singleton and J. Hovden (Eds.). New York, Singapore, John Wiley \& Sons Ltd., pp. 25 - 39.

Business Times. (1998). MAS posts RM257M Net Loss as Forex Losses Cost Mount. Business Times. Singapore

Campbell, T. S., \& W. A. Kracaw. (1993). Financial Risk Management (Fixed Income and Foreign Exchange). New York, Harper Collins College Publishers.

Eales, B. A. (1995). Financial Risk Management. London: McGraw-Hill Book Company.

Hovden, J., \&T.J. Larsson. (1987). Risk: Culture \& Concepts. In WT Singleton \& J. Hovden (Eds.), Risk \& Decision, Wiley, Chichester. pp. 47 - 58

MacCrimmon, K. R., \& D. A. Wehrung. (1990). Characteristics of Risk Taking Executives. Management Science, $36(4), 422-435$.

Manab, N. (2008). Enterprise-Wide Risk Management Implementation, Compliance and Value Creation Among Public Listed Companies in Malaysia. Universiti Teknologi MARA, Unpublished Thesis

Nance, D. R., \& C. W. Smith. et al. (1993). On THe Determinants Of Corporate Hedging. Journal Of Finance, 48(1), 267 - 285. http://dx.doi.org/10.2307/2328889

Penafort, F., \& C. H. Ponnu. (1996). The Role Of Top Management In Implementing Strategies Successfully. Malaysian Management Review, 31(2), 1 - 6.

Rawls, \& Smithson. (1990). How Risk Management Can Increase The Value Of The Firm. Managing Financial Risk - A Guide To Derivative Products, Financial Engineering, and Value Maximization. C. W. Smithson, Clifford W. Smith Jr. and D. S. Wilford. Illinoius, IIrwin Professional Publishing: 538p.

Santomero, A. M. (1995). Financial Risk Management: The Whys And Hows. Journal of Financial Markets, Institutions And Investment, 4(5), 1 - 14. 
Shapiro, A. C., \& S. Titman. (1985). An Integrated Approach To Corporate Risk Management.Midland Corporate Finance Journal, 13(Summer), 41 - 56.

Stoh, P.J. (2005). Enterprise Risk Management at United Health Group. Strategic Finance, 87(7), 26-35

Theil, M., \& Fergusin, W. L. (2003). Risk Management as a Process: An International Perspective. Review of Business, 24, 30 - 35

Vaus, D. A. d. (1993). Surveys In Social Research. London: University College of London Press.

Yazid A. S., Mohd Rasid Hussin, \& Matthias Beck. (2011). Implementing Risk Management: The Case of Malaysian Public Listed Companies. Journal of Risk \& Governance, 1(4). ISSN 1939-5922.

Table 1. CEOs' Traits and Risk Perception - Kruskal-Wallis Test

\begin{tabular}{|c|c|}
\hline & Chi-Square Values \\
\hline Age & $\begin{array}{l}\text { Before crisis } \\
\text { Business risks }-6.179^{*} \\
\text { Financial risks }-10.944^{* * *} \\
\text { Political risks }-7.056^{*} \\
\end{array}$ \\
\hline Experience & $\begin{array}{l}\text { Before crisis } \\
\text { Commodity price risk- } 6.917^{*} \\
\text { During crisis } \\
\text { Interest rate risk- } 7.668^{* *} \\
\text { Foreign exchange risk }-7.454^{*} \\
\text { Current period } \\
\text { Financial risks }-7.495^{*} \\
\text { Interest rate risk }-7.770^{* *} \\
\end{array}$ \\
\hline Ethnic groups & $\begin{array}{l}\text { Before crisis } \\
\text { Financial risks }-6.669^{* * *} \\
\text { Current period } \\
\text { Financial risks }-2.610^{* *}\end{array}$ \\
\hline
\end{tabular}

Table 2. CEOs' Traits and Risk Perception - Kruskal-Wallis Test

\begin{tabular}{|l|l|}
\hline & Chi-Square Values \\
\hline Age & During crisis \\
& Financial risks $-6.491^{*}$ \\
& Foreign exchange risk $-10.149 * * *$ \\
& Commodity price risks $-6.480^{*}$ \\
\hline Experience & Before crisis \\
& Foreign exchange risk- $7.392^{*}$ \\
& Current period \\
& Interest rate risk $-9.851^{* * *}$ \\
\hline
\end{tabular}

\footnotetext{
*** significant at $5 \% \quad *$ significant at $20 \%$
} 


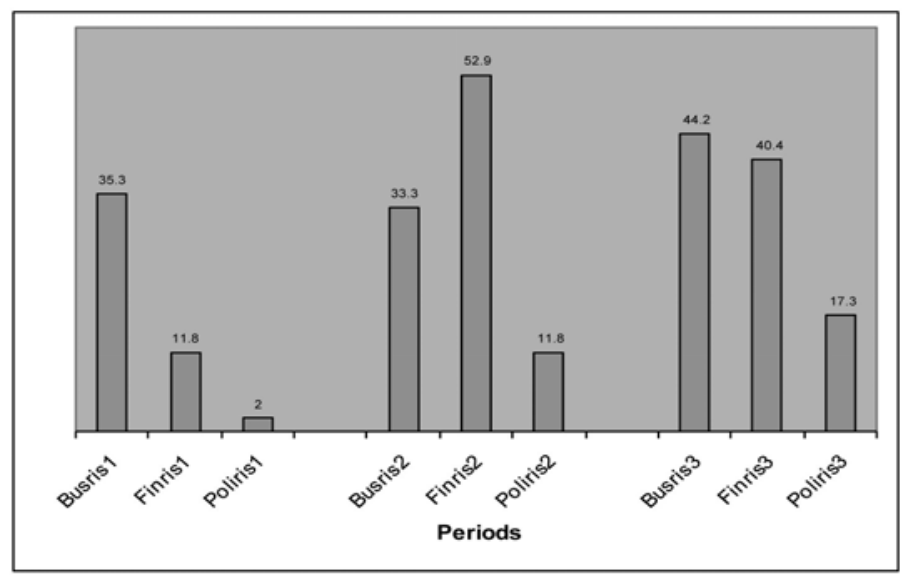

* $\quad 1$ = Before crisis; 2 = During crisis; 3 = After crisis

Figure 1. CEOs' Perceptions of Major Risks Among Companies With Financial Risk Management

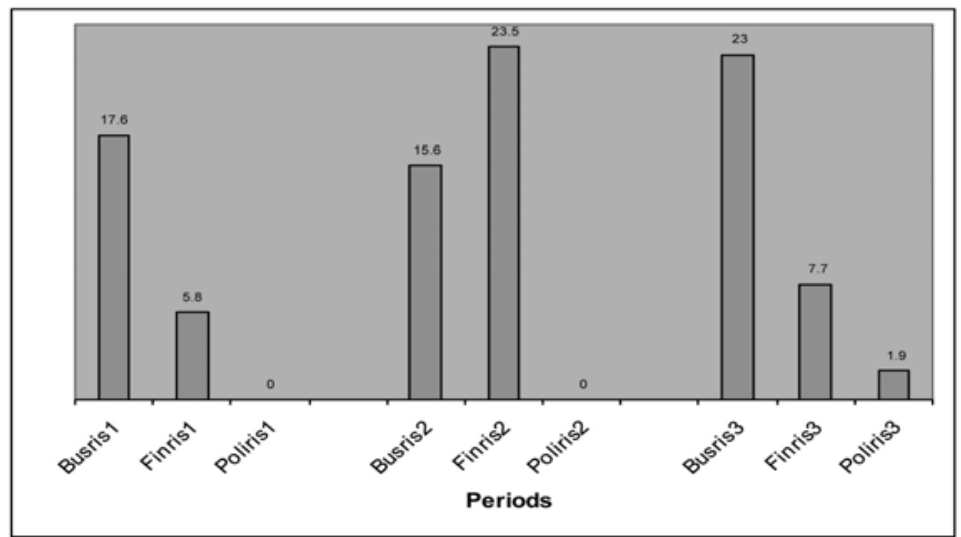

Figure 2. CEOs' Perceptions of Major Risks Among Companies Without Financial Risk Management

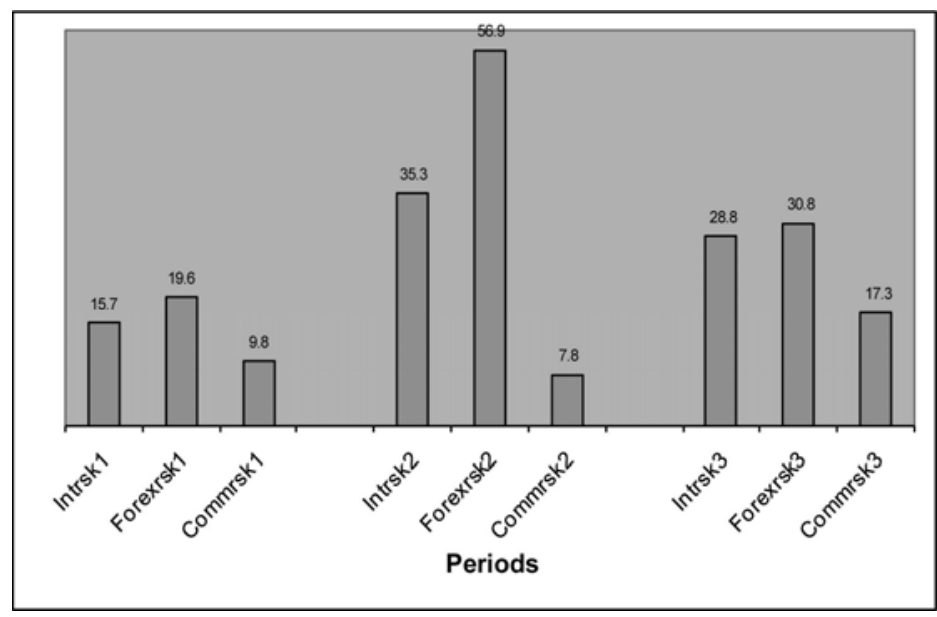

Figure 3. CEOs' Perceptions of Financial Risks Among Companies With Financial Risk Management 


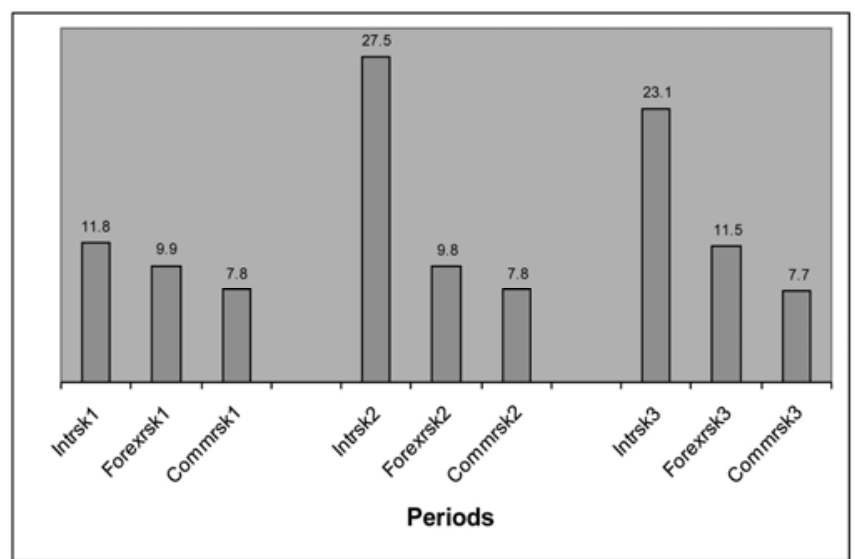

Figure 4. CEOs' Perceptions of Financial Risks Among Companies Without Financial Risk Management 